\title{
Desafios da universidade
}

Duas obras discutem o papel e os dilemas da universidade em um período em que a educação é vista como um dos principais motores do crescimento econômico e social. A tese, nas duas obras, é a de que a universidade está em crise, tanto em seu papel social quanto no econômico.



A universidade e a vida atual: Felini não via filmes Renato Janine Ribeiro Campus

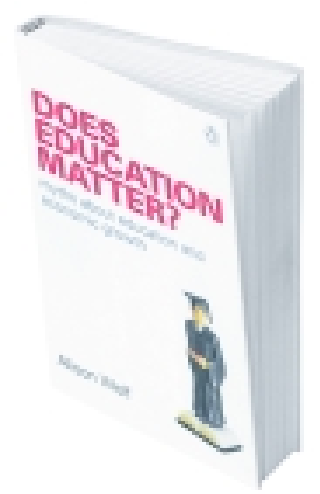

Does education matter? Myths about education and economic growth Alison Wolf Penguin Books

porTatianaTinoco FGV-EAESP

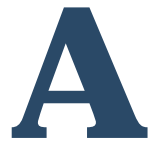
educação é, sem dúvida, um dos temas mais debatidos da vida atual. Carro-chefe das campanhas políticas, especialmente nos anos 1990, ela é vista como uma questão estratégica em um contexto no qual o foco se desloca do processo produtivo para as pessoas e o que realmente importa é o conhecimento.

A crença de que a educação traz progresso econômico tem sua origem na teoria econômica, que a considera como o primeiro elo da cadeia por meio da qual o conhecimento é disseminado na economia, contribuindo para a acumulação de "capital humano". Quanto mais alto esse capital, maior será a produtividade e, conseqüentemente, maior a possibilidade de inovação e bem-estar social.

Hoje não é mais possível discutir a escola ou a universidade de forma isolada, com suas questões internas, ou como uma mera oficina de preparação para o mercado. É preciso questionar seu papel mais amplo no processo de desenvolvimento econômico e social. É em torno desse princípio comum que Alisson Wolf e Renato Janine Ribeiro desenvolvem suas idéias.
Alison Wolf questiona os elevados investimentos feitos pelos governos do Reino Unido na tentativa de aumentar 0 crescimento econômico. A autora não questiona, em nenhum momento, a validade da educação individual; ao contrário, mostra dados que comprovam que, em geral, os indivíduos com maior nível de educação recebem salários maiores do que aqueles de mesmo grupo e idade mas com menor nível de instrução.

A diferença de salário é explicada pelo fato de a educação ser um "bem posicional". Não se trata de ter ou não determinados conhecimentos, mas deter mais conhecimentos do que outras pessoas. Assim, afirma a autora, não há dúvidas de que, do ponto de vista individual, "ter as qualificações corretas, nos ramos corretos, das instituições corretas" é cada vez mais relevante.

Wolf não questiona se a educação básica dada às crianças deve ou não ser garantida pelo governo. Para ela, de fato, o governo deve arcar com esse investimento, que se comprovou eficaz em termos de ganhos econômicos. Trata-se de questionar os gastos exorbitantes em educação superior. 
A expansão da educação, afirma a autora, deixou de ter um motivo externo e passou a ser um fim em si mesmo. Treinamentos, qualificações e vagas nas universidades são tratados como inquestionavelmente desejáveis. Porém, os governos que investem nessa multibilionária indústria da educação desejam apenas o crescimento econômico, um crescimento que, segundo Wolf, não acontece.

Apesar de tratarem de contextos muito diferentes - Reino Unido e Brasil -, os livros de Alison Wolf e Renato Janine Ribeiro têm pelo menos um ponto em comum: a crítica à massificação da educação, decorrente de políticas públicas que privilegiam aspectos econômicos e deixam de lado sua função social. Os dois autores parecem concordar que, quando se acredita na fórmula "mais educação = maior crescimento" e quando 0 acesso à universidade é massificado, passa-se a dar prioridade para variáveis quantitativas, em detrimento de questões qual itativas.

É contraditório pretender expandir a educação para um número cada vez maior de indivíduos tendo, para tanto, soma similar de recursos. A equação só pode ser resolvida pela perda de qualidade. N enhum dos dois autores questiona 0 direito que as pessoas têm de chegar à universidade e obter um diploma; porém, o ingresso de todos na universidade não deve ser uma obrigação, menos ainda uma obrigação do Estado.

0 foco principal de Janine Ribeiro é o papel social da universidade. Ele parte do princípio de que é necessário escutar o que a sociedade diz e quer. Segundo o autor, isso depende da criação de uma relação mais estreita com o mundo externo por parte de pesquisadores, que, talvez, estejam demasiadamente reclusos em seus castel os de vidro.

Janine Ribeiro afirma que nunca, na história, houve tanta demanda social por saber cientifico, mas que a universidade faz pouco para discutir essa demanda, reagindo às solicitações do mercado ou da mídia. Para ele, o papel da universidade deveria ser mais ativo. Ela deveria desenvolver uma nova forma de comunicação com o meio exterior, sintonizando-se com a pauta de assuntos de maior impacto para a sociedade.

0 que os dois autores mostram éque a universidade vive uma crise paradoxal. Ao privilegiar o mercado, não consegue gerar o grau de crescimento econômico que se esperava; e, ao privilegiar a esfera social, não consegue atender à demanda por pesquisas que gerem impacto fora dos limites da própria academia.

Tatiana Tinoco

M estranda em Administração de Empresas pela FGV-EAESP

E-mail: tatianat@fgvsp.br 